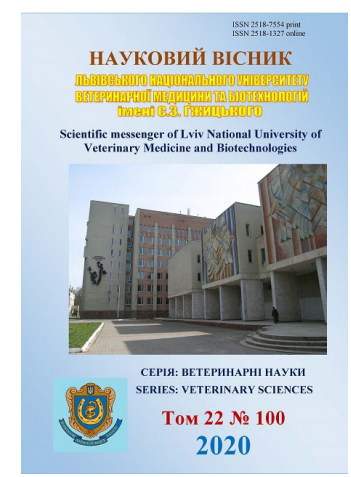

Науковий вісник Дьвівського національного університету ветеринарної медицини та біотехнологій імені С.3. Гжицького. Серія: Ветеринарні науки

\author{
Scientific Messenger of Lviv National University \\ of Veterinary Medicine and Biotechnologies. \\ Series: Veterinary sciences
}

doi: 10.32718/nvlvet10007

https://nvlvet.com.ua/index.php/journal

UDC 619.615

\title{
The effect of bendamine on the intensity of lipid peroxidation and the activity of the antioxidant defense system of blood in rats in experimental doxorubicin- induced cardiomyopathy
}

\author{
I. S. Varkholiak ${ }^{1}$, B. V. Gutyj ${ }^{1}$, V. I. Kushnir ${ }^{2}$, N. V. Nazaruk ${ }^{1}$, O. I. Lisnyak ${ }^{1}$, T. V. Yurynets ${ }^{2}$ \\ ${ }^{1}$ Stepan Gzhytskyi National University of Veterinary Medicine and Biotechnologies Lviv, Ukraine \\ ${ }^{2}$ State Scientific-Research Control Institute of Veterinary Medicinal Products and Feed Additives, Lviv, Ukraine
}

Article info

Received 29.09.2020

Received in revised form 29.10.2020

Accepted 30.10.2020

Stepan Gzhytskyi National University of Veterinary Medicine and Biotechnologies Lviv,

Pekarska Str., 50, Lviv, 79010, Ukraine.

Tel.: +38-096-486-26-85

E-mail:irynkavet@ukr.net

State Scientific-Research Control Institute of Veterinary Medicinal Products and Feed Additives,

Donetska Str., 11, Lviv,

79019, Ukraine.
Varkholiak I. S., Gutyj B. V., Kushnir V. I., Nazaruk N. V., Lisnyak O. I., \& Yurynets T. V. (2020). The effect of bendamine on the intensity of lipid peroxidation and the activity of the antioxidant defense system of blood in rats in experimental doxorubicin-induced cardiomyopathy. Scientific Messenger of Lviv National University of Veterinary Medicine and Biotechnologies. Series: Veterinary sciences, 22(100), 36-40. doi: 10.32718/nvlvet10007

Experimental studies obtained in recent years indicate the urgency of developing drugs of complex action to prevent the development of cardiovascular disease in dogs. This requires a much deeper study of the pathogenesis of heart failure, including cardiomyopathy. The aim of the study was the effect of bendamine on the intensity of lipid peroxidation and the activity of the antioxidant defense system of blood in rats in experimental doxorubicin-induced cardiomyopathy. To reproduce heart failure in rats, an experimental model was used by intraperitoneal administration of doxorubicin at a dose of $2.5 \mathrm{mg} / \mathrm{kg}$ 3 times a week for two weeks. The study was performed on white sexually mature young male Wistar rats weighing 180-200 g, which were kept on the standard diet of the institute vivarium of the State Research Control Institute of Veterinary Drugs and Feed Additives. For the study, three groups of rats of 6 animals in each were formed: control group - intact animals; experimental group $R_{l}$, in which animals were simulated doxorubicin-induced cardiomyopathy by intraperitoneal administration of doxorubicin; experimental group $R_{2}$, in which animals after injection of doxorubicin, intragastrically administered the drug "Bendamine" at a dose of $20 \mathrm{mg} / \mathrm{kg}$. According to studies, doxorubicin intoxication in rats enhances LPO processes, as indicated by an increased content of lipid hydroperoxides by $47.4 \%$, diene conjugates - by $21.4 \%$ and TBA-active products - by $24.9 \%$ for animals of the control group. Doxorubicin cardiomyopathy in rats has a decrease in the activity of antioxidant enzymes in the blood of animals. In particular, the activity of catalase decreases by $36.9 \%(P \leq 0.001)$, and the activity of SOD - by $20.3 \%(P \leq 0.001)$. In the study of the activity of the glutathione link of the antioxidant defense system, similar changes were found as in the study of the activity of catalase and SOD. The use of the drug "Bendamine" in the rats of the experimental group helped to inhibit the excessive formation of lipid peroxidation products and increase the activity of both enzymatic and non-enzymatic parts of the antioxidant system.

Key words: pharmacology, bendamine, heart failure, cardiomyopathy, antioxidant status.

\section{Вплив бендаміну на інтенсивність пероксидного окиснення ліпідів та активність системи антиоксидантного захисту крові щурів за експериментальної доксорубіцин-індукованої кардіоміопатії}

\footnotetext{
I. С. Вархоляк ${ }^{1}$, Б. В. Гутий${ }^{1}$, В. І. Кушнір ${ }^{2}$, Н. В. Назарук ${ }^{1}$, О. І. Лісняк ${ }^{1}$, Т. В. Юринець ${ }^{2}$

${ }^{1}$ Львівський національний університет ветеринарної медицини та біотехнологій імені С. 3. Гэницького, м. Львів, Украӥна
} 
${ }^{2}$ Державний науково-дослідний контрольний інститут ветеринарних препаратів та кормових добавок, м. Львів, Україна

Експериментальні дослідження, одержанні за останні роки, вказують на актуальність розробки лікарських засобів комплексної дї для попередження розвитку серцево-судинної патологї у собак. Це вимагає значно глибшого вивчення патогенезу сериевої недостатності, в тому числі кардіоміопатії. Метою роботи було дослідити вплив бендаміну на інтенсивність пероксидного окиснення ліпідів та активність системи антиоксидантного захисту крові щурів за експериментальної доксорубіцин-індукованої кардіоміопатії. Для відтворення серцевої недостатності на шурах було використано експериментальну модель иляхом внутрішньочеревного введення доксорубіцину в дозі 2,5 мг/кг 3 рази на тиждень протягом двох тижнів. Дослідження проводили на білих статево-зрілих молодих шурах-самиях лінї Вістар масою тіла 180-200 2, яких утримували на стандартному раиіоні інститутського віварію Державного науково-дослідного контрольного інституту ветеринарних препаратів та кормових добавок. Для проведення досліджень було сформовано три групи щурів по 6 тварин у кожній: контрольна група - інтактні тварин; дослідна група $Д_{1}$, в якій тваринам моделювали доксорубіцин-індуковану кардіоміопатію иляхом внутрішньочеревного введення доксорубіцину; дослідна група Д, в якій тваринам після ін 'єкиї доксорубічину, внутрішньошлунково вводили препарат “Бендамін” у дозі 20 мг/кг. Згідно з проведеними дослідженнями встановлено, шо за доксорубіцинової інтоксикацї у щурів посилюються процеси ПОЛ, на що вказує підвищений вміст гідроперекисів ліпідів на 47,4 \%, дієнових кон'югатів - на 21,4 \% та ТБК-активних продуктів - на 24,9 \% щооо тварин контрольної групи. За доксорубіцинової кардіоміопатї у шурів спостерігається зниження активності антиоксидантних ензимів у крові тварин. Зокрема, активність каталази зменшується на 36,9 \% (P $\leq 0,001)$, а активність СОД - на 20,3 \% $(P \leq 0,001)$. При дослідженні активності глутатіонової ланки системи антиоксидантного захисту встановлено аналогічні зміни, як і при дослідженні активності каталази та СОД. Застосування препарату “Бендамін” щурам дослідної групи сприяло гальмуванню надмірному утворенню продуктів пероксидного окиснення ліпідів та підвищенню активності як ензимної, так $і$ неензимної ланки антиоксидантної системи.

Ключові слова: фармакологія, бендамін, серцева недостатність, кардіоміопатія, антиоксидантний статус.

\section{Вступ}

Патології серця і судин у собак трапляються дуже часто, проте їхні причини не завжди відомі. Патологія серця у тварин може клінічно не проявлятися тривалий час, що створює труднощі для постановки діагнозу (Oldach et al., 2019; Kochie et al., 2020). У разі виявлення у собак серцево-судинної патології важливим $\epsilon$ встановити ступінь розладів гемодинаміки, а також захворювання інших органів, що можуть бути вирішальними для перебігу та прогнозу (Tjostheim et al., 2019; Sarcinella et al., 2020). Відомо, що 10 \% всіх тварин страждають патологіями серцево-судинної системи різного ступеня вираженості (Zhulikova, 2016; Varkholiak \& Gutyj, 2020). На прийом до кардіолога потрапляють тварини різноманітних порід та вікових груп. Найчастіше у великих порід собак реєструються кардіоміопатії (Fuentes et al., 2002; Varcholyak \& Gutyi, 2019) (частіше дилатаційна, рідше аритмогенна), у дрібних порід - клапанні патології (а саме - ендокардіоз атріовентрикулярних клапанів). Рідше трапляються перикардити, вроджені вади та iнше (Undhad et al., 2012; Varkholiak, 2016).

Порушення в роботі серцево-судинної системи призводять до незворотних процесів у всьому організмі, які в більшості випадків закінчуються загибеллю тварин. Варто зазначити, що дана патологія нерідко протягом тривалого часу протікає у прихованій формі, яка не проявляється клінічно і не викликає настороженості у власників. У зв'язку з цим тварини потрапляють до фахівців у період розвитку декомпенсації хронічної серцевої недостатності. До того ж своєчасне виявлення патології і початок проведення лікування можуть значно продовжити життя хворої тварини (Yata et al., 2019).

Розробка, дослідження та впровадження нових кардіопрепаратів для профілактики і лікування тварин за серцево-судинних захворювань, у механізмі яких відбувається розвиток оксидативного стресу, є на часі і мають значну перспективу. У цьому плані доцільним $\epsilon$ використання у ветеринарній медицині за серцевої недостатності у тварин інгібіторів фосфодиестерази-3 та антиоксидантів (Varkholiak \& Gutyj, 2018; 2019). Саме тому актуальним є розробка вітчизняного кардіопрепарату для собак за патологій серцево-судинної системи та дослідження його фармакотоксикологічних параметрів.

Метою роботи було дослідити вплив бендаміну на інтенсивність пероксидного окиснення ліпідів та активність системи антиоксидантного захисту крові щурів за експериментальної доксорубіциніндукованої кардіоміопатії.

\section{Матеріал і методи досліджень}

Дослідження проводили на білих статево-зрілих молодих щурах-самцях лінії Вістар масою тіла 180200 г, яких утримували на стандартному раціоні інститутського віварію Державного науково-дослідного контрольного інституту ветеринарних препаратів та кормових добавок. Протягом усього експерименту щурів утримували на збалансованому раціоні, що містив усі необхідні компоненти, питну воду тварини отримували без обмежень.

Для створення моделі доксорубіцин-індукованої кардіоміопатії було відібрано 24 щурів-самців. Тварини були розподілені на 3 групи по 6 тварин у кожній: контрольна група - інтактні тварин; дослідна група Д1, в якій тваринам моделювали доксорубіциніндуковану кардіоміопатію шляхом внутрішньочеревного введення доксорубіцину в дозі 2,5 мг/кг 3 рази на тиждень протягом двох тижнів; дослідна група Д 2 , в якій тваринам після ін'єкції доксорубіцину, внутрішньошлунково вводили препарат "Бендамін" у дозі $20 \mathrm{мг/Кг.}$

Уміст продуктів ПОЛ - гідроперекисів ліпідів, дієнових кон'югатів та ТБК-активних продуктів, активність антиоксидантних ензимів - супероксиддисмута- 
зи, каталази, глутатіонпероксидази та глутатіонредуктази, а також рівень відновленого глутатіону визначали за методами описаними в довіднику (Vlizlo, 2012).

Усі маніпуляції з тваринами проводили відповідно до Європейської конвенції про захист хребетних тварин, які використовуються для експериментальних i наукових цілей (Страсбург, 1986 р.).

Аналіз результатів досліджень проводили за допомогою пакету програм Statistica 6.0. Вірогідність різниць оцінювали за t-критерієм Стьюдента. Результати вважали вірогідними при $\mathrm{P} \leq 0,05$.

\section{Результати та їх обговорення}

На основі проведених досліджень встановлено, що у тварин за експериментальної хронічної інтоксикації доксорубіцином посилюються процеси пероксидного окиснення ліпідів та утворення активних форм кисню. Активація процесів вільнорадикального окиснення призводять до порушення фізико-хімічної структури та властивостей мембран, інгібуванню мембранозв'язаних та цитоплазматичних ензимів, а також порушенню біоенергетичних процесів, що у подаль- шому сприяє розвитку оксидативного стресу, який є важливим патогенетичним фактором розвитку багатьох патологічних процесів.

Отже, у тварин з модельованою кардіоміопатією розвивалась надмірна активація пероксидного окиснення ліпідів, на що вказує високий рівень первинних, проміжних та кінцевих продуктів ПОЛ (табл. 1).

При дослідженні рівня гідроперекисів ліпідів у крові щурів за інтоксикації доксорубіцином встановлено підвищення його рівня на 47,4 \%. При задаванні щурам дослідної групи Д2 препарату "Бендамін" встановлено зниження рівня гідроперекисів ліпідів на 33,5 \% порівняно з першою дослідною групою щурів, яким експериментально викликали кардіоміопатію шляхом введення доксорубіцину.

При дослідженні проміжних продуктів ПОЛ встановлено їхне вірогідне збільшення у крові першої дослідної групи на 21,4% порівняно 3 показниками контрольної групи. Найнижчим рівень дієнових кон'югатів спостерігали у другої дослідної групи, яким задавали препарат “Бендамін”, де відповідно він знизився на 26,5 \% порівняно 3 першою дослідною групою.

\section{Таблиця 1}

Показники інтенсивності пероксидного окиснення ліпідів у крові щурів за експериментального моделювання серцевої недостатності та дії коригуючих чинників $(\mathrm{M} \pm \mathrm{m}, \mathrm{n}=6)$

\begin{tabular}{lccc}
\hline \multicolumn{1}{c}{ Показники } & \multicolumn{3}{c}{ Групи тварин } \\
\cline { 2 - 4 } & Контрольна & Д $_{1}$ & Д $_{2}$ \\
\hline Гідроперекиси ліпідів, одЕ/мл & $0,247 \pm 0,0218$ & $0,364 \pm 0,0262^{* *}$ & $0,242 \pm 0,0156$ \\
Дієнові кон'югати, ммоль/л & $0,028 \pm 0,004$ & $0,034 \pm 0,003^{*}$ & $0,025 \pm 0,002$ \\
ТБК-акт. продукти, ммоль/л & $4,45 \pm 0,22$ & $5,56 \pm 0,36 *$ & $4,39 \pm 0,30$ \\
\hline
\end{tabular}

При дослідженні кінцевих продуктів ПОЛ встановлено підвищення рівня ТБК-активних продуктів у першій дослідній групі щурів, де порівняно 3 контрольною групою тварин він зріс на 24,9 \% відповідно.

Підвищення вмісту продуктів ПОЛ: гідроперекисів ліпідів, дієнових кон'югатів та ТБК-активних продуктів у крові щурів з експериментальною інтоксикацією доксорубіцином вказує про розвиток оксидаційного стресу. Ці результати узгоджуються 3 даними літератури щодо активації вільнорадикальних реакцій та процесів ПОЛ у крові тварин під впливом доксорубіцину.

Таблиця 2

Показники системи антиоксидантного захисту організму щурів за експериментального моделювання серцевої недостатності та дії бендаміну $(\mathrm{M} \pm \mathrm{m}, \mathrm{n}=6)$

\begin{tabular}{lccr}
\hline \multicolumn{1}{c}{ Показники } & \multicolumn{3}{c}{ Групи тварин } \\
\cline { 2 - 4 } & Контрольна & \multicolumn{1}{c}{$Д_{1}$} & \multicolumn{2}{c}{ Д $_{2}$} \\
\hline Супероксиддисмутаза, ум. од./1 мг білка & $4,52 \pm 0,18$ & $3,15 \pm 0,10^{* * *}$ & $4,61 \pm 0,22$ \\
Каталаза, мккат/л & $4,25 \pm 0,34$ & $2,68 \pm 0,26^{* *}$ & $4,41 \pm 0,30$ \\
Глутатіонпероксидаза, нмоль глутатіону/хв на 1 мг білка & $28,07 \pm 1,47$ & $23,18 \pm 1,75^{*}$ & $28,12 \pm 1,42$ \\
Глутатіонредуктазна, нмоль NADPH/хв на 1 мг білка & $9,63 \pm 0,57$ & $7,29 \pm 0,66^{*}$ & $9,59 \pm 0,77$ \\
Відновлений глутатіон, мкмоль/мл & $0,521 \pm 0,012$ & $0,436 \pm 0,025^{*}$ & $0,533 \pm 0,020$ \\
\hline
\end{tabular}

Так, активність супероксиддисмутази у крові щурів першої дослідної групи знизилася на 30,3\%, а
При введенні препарату “Бендамін” щурам другої дослідної групи встановлено зниження його рівня до 4,39 \pm 0,30 ммоль/л. Дані результати досліджень вказують на антиоксидантні властивості препарату "Бендамін”, який сприяв пригніченню процесів ПОЛ та зниженню його продуктів у крові дослідних щурів.

Введення доксорубіцину експериментальним тваринам супроводжувалось пригніченням системи антиоксидантного захисту, на що вказувало зниження активності супероксиддисмутази та каталази у крові першої дослідної групи (табл. 2). активність каталази відповідно - на 36,9 \% порівняно 3 контрольною групою тварин. 
3 табл. 2 видно, що позитивний вплив препарату “Бендамін” проявлявся підвищенням активності супероксиддисмутази та каталази у крові щурів другої дослідної групи. У другої дослідної групи активність вказаних ензимів доходила до величин контрольної групи, де відповідно була у межах 4,61 $\pm 0,22$ ум. од./1 мг. білка (СОД) і 4,41 \pm 0,30 мккат/л (каталаза).

Важливою ланкою системи антиоксидантного захисту $є$ глутатіонова система. Вона складається 3 відновленого глутатіону та ряду ензимів, а саме глутатіопероксидази та глутатіонредуктази. Узгоджена дія всіх пї компонентів (відновленого глутатіону, глутатіонпероксидази, глутатіонредуктази) сприяє встановленню оптимального вмісту пероксидних сполук, збереженню антиоксидантного гомеостазу (Martyshuk \& Gutyj, 2019; Grymak et al., 2020).

Глутатіон $є$ центральним компонентом системи антиоксидантного захисту майже всіх клітин і органів. Його антиоксидантна дія пов'язана 3 перенесенням сульфгідрильних груп. За активності глутатіонпероксидази він окиснюється, а за активності глутатіонредуктази переводить глутатіон у відновлену форму (Martyshuk et al., 2018; Gutyj et al., 2018).

Розвиток кардіоміопатії, індукованої доксорубіцином, характеризувався зниженням рівня відновленого глутатіону, так, у крові щурів першої дослідної групи встановлено зниження його рівня на 16,3 \% порівняно 3 контрольної групою тварин. Застосування препарату “Бендамін” сприяло підвищенню рівня даного показника у крові щурів другої дослідної групи на 22,2% порівняно з хворими тваринами.

При дослідженні ензимної ланки глутатіонової системи встановлено зниження активності глутатіонпероксидази та глутатіонредуктази у крові щурів, яким вводили доксорубіцин, 3 метою розвитку ексмпериментальної хронічної кардіоміопатії. Встановлено зниження активності вказаних ензимів у крові першої дослідної групи на 17,4 і 24,3 \% порівняно з інтактними щурами.

Добрі антиоксидантні властивості проявив препарат “Бендамін”, який при введенні щурам другої дослідної групи за умов інтоксикації доксорубіцином, сприяв підвищенню активності глутатіонпероксидази до $28,12 \pm 1,42$ нмоль глутатіону/хв на 1 мг білка та активності глутатіонредуктази - до 9,59 \pm 0,77 нмоль NADPH/хв на 1 мг білка.

Отже, на основі проведених досліджень встановлено позитивний вплив препарату «Бендамін» на показники системи антиоксидантного захисту крові щурів за умов експериментальної доксорубіциніндукованої серцевої недостатності.

\section{Висновки}

За доксорубіцинової інтоксикації у щурів встановлено зниження активності системи антиоксидантного захисту у щурів (СОД на 30,3 \%, КТ - на 36,9 \%, ГП на $17,4 \%$, ГР - на 24,3 \%, відновлений глутатіон - на $16,3 \%$ ) спостерігається посилення процесів ПОЛ (підвищення гідроперекисів ліпідів на 47,3%, дієно- вих кон'югатів - на 21,4 \%, ТБК-активних продуктів на $24,9 \%$ ).

Уведення щурам препарату “Бендамін”, на тлі змодельованої серцевої недостатності покращує антиоксидантний статус організму щурів.

\section{Подяка}

Ця робота була фінансово підтримана Міністерством освіти і науки України (0120U101999).

\section{References}

Fuentes, V. L., Corcoran, B., French, A., Schober, K. E., Kleemann, R., \& Justus, C. (2002). A double-blind, randomized, placebo-controlled study of pimobendan in dogs with dilated cardiomyopathy. J Vet Int Med, 16, 255-261. doi: 10.1111/j.1939-1676.2002.tb02366.x

Grymak, Y., Skoromna, O., Stadnytska, O., Sobolev, O., Gutyj, B., Shalovylo, S., Hachak, Y., Grabovska, O., Bushueva, I., Denys, G., Hudyma, V., Pakholkiv, N., Jarochovich, I., Nahirniak, T., Pavliv, O., Farionik, T., Bratyuk, V. (2020). Influence of "Thireomagnile" and "Thyrioton" preparations on the antioxidant status of pregnant cows. Ukrainian Journal of Ecology, 10(1), 122-126. doi: 10.15421/2020_19.

Gutyj, B. V., Gufriy, D. F., Binkevych, V. Y., Vasiv, R. O., Demus, N. V., Leskiv, K. Y., Binkevych, O. M., \& Pavliv, O. V. (2018). Influence of cadmium loading on glutathione system of antioxidant protection of the bullocks'bodies. Scientific Messenger of Lviv National University of Veterinary Medicine and Biotechnologies, 20(92), 34-40. doi: 10.32718/nvlvet9207.

Kochie, S. L., Schober, K. E., Rhinehart, J., Winter, R. L., Bonagura, J. D., Showers, A., \& Yildez, V. (2020). Effects of pimobendan on left atrial transport function in cats. J Vet Intern Med, 2020. doi: 10.1111 jvim. 15976 .

Martyshuk, T. V., \& Gutyj, B. V. (2019). Influence of feed additive "Butaselmevit-Plus" on antioxidant status of rats in conditions of oxidative stress. Scientific Messenger of Lviv National University of Veterinary Medicine and Biotechnologies. Series: Agricultural sciences, 21(90), 76-81. doi: 10.32718/nvlvet-a9013.

Martyshuk, T. V., Gutyj, B. V., \& Vishchur, O. I. (2018). Indicators of functional and antioxidant liver status of rats under oxidative stress conditions and on the action of the liposomal drug "Butaselmevit". Scientific Messenger of Lviv National University of Veterinary Medicine and Biotechnologies, 20(89), 100-107. doi: $10.32718 /$ nvlvet8919.

Oldach, M. S., Ueda, Y., Ontiveros, E. S., Fousse, S. L., Harris, S. P., \& Stern, J. A. (2019). Cardiac Effects of a Single Dose of Pimobendan in Cats With Hypertrophic Cardiomyopathy; A Randomized, Placebo-Controlled, Crossover Study. Front Vet Sci., 6, 15. doi: 10.3389/fvets.2019.00015.

Sarcinella, F., Neves, J., Maddox, T.W., Hodgkiss-Geere, H.M., Bode, E.F., Dukes-McEwan, J. (2020). Effect of pimobendan on left atrial function in dogs with 
preclinical myxomatous mitral valve disease. Open Vet J, 9(4), 375-383. doi: 10.4314/ovj.v9i4.16.

Tjostheim, S. S., Kellihan, H. B., Grint, K. A., \& Stepien, R. L. (2019). Effect of sildenafil and pimobendan on intracardiac heartworm infections in four dogs. J Vet Cardiol., 23, 96-103. doi: 10.1016/j.jvc.2019.02.001.

Undhad, V. V., Fefar, D. T., Jivani, B. M., Gupta, H., Ghodasara, D. J., Joshi, B. P. \& Prajapati, K. S. (2012). Cardiac troponin: an emerging cardiac biomarker in animal health. Vet. World, 5, 508-511. doi: 10.5455/vetworld.2012.508-511.

Varcholyak, I. S., \& Gutyi, B. V. (2019). Determination of the chronic toxicity of preparation "Bendamin" on laboratory animals. Theoretical and Applied Veterinary Medicine, 7(2), 63-68. doi: 10.32819/2019.71011.

Varkholiak, I. S. (2016). The usage of medicines at the cardiovascular pathologies in dogs and cats. Scientific Messenger LNUVMBT named after S.Z. Gzhytskyj, 18, 3(71), 261-265. https://nvlvet.com.ua/index.php/ journal/article/view/974.

Varkholiak, I. S., \& Gutyj, B. V. (2018). Determination of acute toxicity of "Bendamin" drug in laboratory animals. Scientific Messenger of Lviv National University of Veterinary Medicine and Biotechnologies, 20(92), 209-212. doi: 10.32718/nvlvet9243.

Varkholiak, I. S., \& Gutyj, B. V. (2019). The degree of cumulation of the "Bendamin" drug in the body of white rats. Scientific Messenger of Lviv National
University of Veterinary Medicine and Biotechnologies. Series: Veterinary sciences, 21(94), 82-85. doi: 10.32718 /nvlvet9415.

Varkholiak, I. S., \& Gutyj, B. V. (2020). The influence of the preparation "Bendamin" on the morphological and biochemical indices of blood of rats in experimental modeling of heart failure. Ukrainian Journal of Veterinary and Agricultural Sciences, 3(1), 38-41. doi: 10.32718/ujvas3-1.07.

Vlizlo, V. V., Fedoruk, R. S., \& Raty`ch, I. B. (2012). Laboratorni metody' doslidzhen' u biologiyi, tvary`nny`cztvi ta vetery`narnij medy'cy'ni: dovidny'k. L`viv: Spolom (in Ukrainian).

Yata, M., Kooistra, H. S., \& Beijerink, N. J. (2019). Cardiorenal and endocrine effects of synthetic canine BNP1-32 in dogs with compensated congestive heart failure caused by myxomatous mitral valve disease. J Vet Intern Med., 33(2), 462-470. doi: 10.1111/jvim.15416.

Zhulikova, O. A. (2016). Monitoring rasprostranenija serdechno-sosudistyh zabolevanij sredi koshek i sobak v g. Blagoveshhensk amurskoj oblasti. Dal'nevostochnyj agrarnyj vestnik, 2(38), 49-56. https://cyberleninka.ru/article/n/monitoringrasprostraneniya-serdechno-sosudistyh-zabolevaniysredi-koshek-i-sobak-v-g-blagoveschensk-amurskoyoblasti (in Russian). 